Int. J. Dev. Biol. 50: 553-560 (2006)

doi: $10.1387 / \mathrm{ijdb} .052094 \mathrm{vv}$

Original Article

\title{
Thyroid hormone receptor expression in the obligatory paedomorphic salamander Necturus maculosus
}

\author{
VIRGINIE VLAEMINCK-GUILLEM ${ }^{1}$, RACHID SAFI ${ }^{1}$, PHILIPPE GUILLEM ${ }^{2}$, EMMANUELLE LETEURTRE ${ }^{3}$, \\ MARTINE DUTERQUE-COQUILLAUD ${ }^{4}$ and VINCENT LAUDET ${ }^{*}, 1$ \\ ${ }^{1}$ LBMC, CNRS UMR 5161, INRA LA 1237, Ecole Normale Supérieure Lyon, ${ }^{2}$ Department of Anatomy, University of Medicine Henri
Warembourg, Lille, ${ }^{3}$ Department of Pathology, University Hospital, Lille and ${ }^{4}$ CNRS UMR 8526, Institut de Biologie de Lille, France
}

ABSTRACT Amphibian metamorphosis is under the strict control of thyroid hormones (TH). These hormones induce metamorphosis by controlling gene expression through binding to thyroid hormone receptors (TRs). Necturus maculosus is considered to be an obligatory paedomorphic Amphibian since metamorphosis never occurs spontaneously and cannot be induced by pharmacological means. Since metamorphosis depends on the acquisition of response of tadpole tissues to thyroid hormone, we aimed to determine TR gene expression patterns in Necturus maculosus as well as the expression of two TH-related genes: Cytosolic Thyroid Hormone-Binding Protein (CTHBP)-M2-pyruvate kinase, a gene encoding a cytosolic TH binding protein and stromelysin 3, a direct TH target gene in Xenopus laevis. Tissue samples were obtained from specimens of Necturus maculosus. We performed in situ hybridization using non-cross-hybridizing RNA probes obtained from the cloned Necturus TR $\alpha$ and TR $\beta$ genes. We found clear expression of Necturus TR $\alpha$ gene in several tissues including the central nervous system, epithelial cells of digestive and urinary organs, as well as myocardium and skeletal muscle. TR $\beta$ was also expressed in the brain. In other tissues, hybridization signals were too low to draw reliable conclusions about their precise distribution. In addition, we observed that the expression of CTHBP and ST3 is largely distinct from that of TRs. The fact that we observed a clear expression of TR $\alpha$ and TR $\beta$ which are evolutionary conserved, suggests that Necturus tissues express TRs. Our results thus indicate that, in contrast to previously held hypotheses, Necturus tissues are TH responsive.

KEY WORDS: amphibian, metamorphosis, paedomorphosis, thyroid hormone

\section{Introduction}

The development of Amphibians is characterized by metamorphosis, an important postembryonic process by which nonreproductive structures of the larva change drastically to an adult form during a brief discrete period (see Shi, 2000) for a review). Despite the extensive and dramatic changes, Amphibian metamorphosis proved to be largely under the control of a single hormone, i.e. thyroid hormone (TH) (Leloup and Buscaglia 1977). As thyroid gland grows under the control of hypothalamus and pituitary and as levels of circulating $\mathrm{TH}$ rise, the sequential changes suggestive of metamorphosis occur (Leloup and Buscaglia 1977). TH controls metamorphosis through gene expression regulation by $\mathrm{TH}$ receptors (TRs). TR expression proved to correlate with metamorphosis since high levels of their mRNAs and proteins are present in a given organ when it undergoes metamorphosis, while low levels are generally ob- served in the same organs before or after metamorphosis (Baker and Tata, 1990, Yaoita and Brown, 1990, Banker et al., 1991, Kawahara et al., 1991, Eliceiri and Brown, 1994). In particular, in Xenopus laevis, TR $\beta$ mRNA and protein are low during premetamorphosis (larval growth without obvious organs/tissue transformation) and increase dramatically just before the prometamorphosis (proper beginning of metamorphosis with hindlimb development). Their levels reach their maximum during metamorphosis climax. To facilitate dramatic changes needed within this very short developmental period, liganded-TR $\beta$ autoregulates its own expression (Tata et al., 1993), through at least one TRE in its promoter (Ranjan et al., 1994, Machuca et al., 1995, Wong et al., 1998).

Abbreviations used in this paper: CTHBP, cytosolic thyroid hormone-binding protein; HES, hematoxylin eosin safran; ST, stromelysin; TH, thyroid hormone; TR, thyroid hormone receptor.

\footnotetext{
*Address correspondence to: Dr. Vincent LAUDET. Laboratoire de Biologie Moléculaire de la Cellule, CNRS UMR 5161, Ecole Normale Supérieure de Lyon 46 allée d'Italie, 69394 Lyon cedex 07, France. Fax: +33-4-7272-8080. e-mail: vincent.laudet@ens-lyon.fr
} 

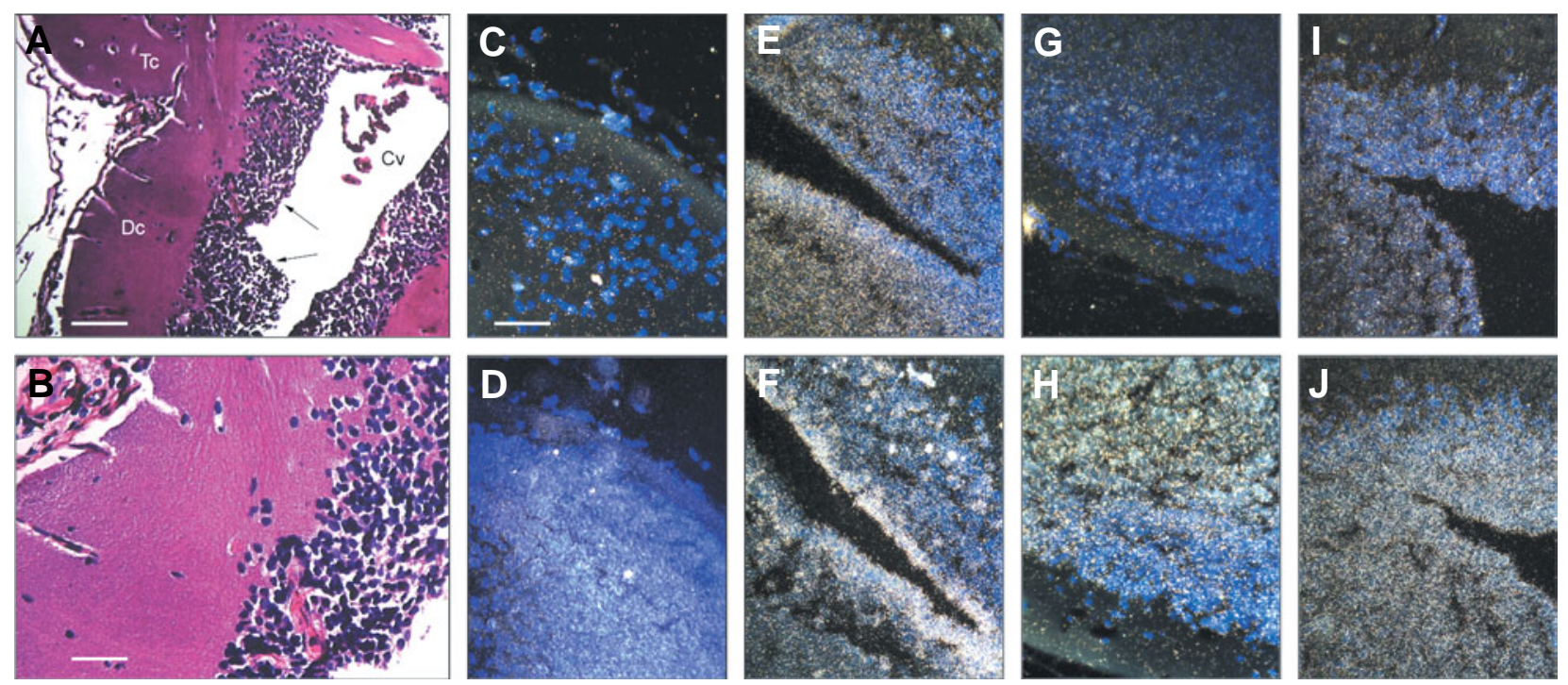

Fig. 1. Expression of $\mathbf{C T H B P}$, stromelysin 3,TR $\boldsymbol{\alpha}$ and $\boldsymbol{T} \boldsymbol{R} \boldsymbol{\beta}$ genes in Necturus maculosus brain. (A,B) Longitudinal sections of the brain were stained with HES (bars in A,B represent $5.7 \mu \mathrm{m}$ and $2.4 \mu \mathrm{m}$ respectively). The larval state is suggested by the neural tube-like appearance of the brain, i.e. juxtaposition of primitive cerebral vesicles, such as telencephalic (TC) and diencephalic (Dc) vesicles shaped as a tube digged by a cavity (CV) lined by neuroepithelial cells (arrows). Adjacent sections were hybridized with either CTHBP sense (C), CTHBP antisense (D), stromelysin 3 sense (E), stromelysin 3 antisense (F), TR $\alpha$ sense (G), TR $\alpha$ antisense (H), TR $\beta$ sense (I), or TR $\beta$ antisense (J) probes (bar, $130 \mu \mathrm{m})$. Expression was restricted to neuronal periventricular area of telencephalic vesicles and diencephalons (arrows).

Some Amphibian species that do not undergo metamorphosis are depicted as paedomorphic (Rosenkilde and Ussing, 1996, Stebbins and Cohen, 1997). Extensive among Urodela, paedomorphosis is defined as the retention of larval characters in reproducing adults. Paedomorphic Amphibian species can be grouped in three types according to the degree of metamorphic failure: accidental, facultative or obligatory. Accidental or geographic paedomorphosis is expressed by only some populations of the species (e.g. Alpine lakes salamanders), facultative paedomorphosis by some individuals of a single population (e.g. axolotl Ambystoma mexicanum which can undergo metamorphosis after TH treatment; the situation being quite complex in Ambystoma (see Voss and Smith, 2005) and references therein) and obligatory paedomorphosis by all individuals of the species. Although geographic paedomorphosis is thought to result from hypothalamic blockade due to unfavorable environmental conditions, the mechanisms underlying facultative and obligatory neotenies remain to be determined (Stebbins and Cohen, 1997, Voss and Smith, 2005).

The so-called mudpuppy, Necturus maculosus, is an obligatory paedomorphic Urodela. It is permanently paedomorphic since metamorphosis never occurs spontaneously and cannot be induced by pharmacological means (Harris, 1956, Larsen, 1968). Thyroid glands of Necturus are however TSH-responsive and capable of function. Implants of Necturus thyroid tissue have been shown to bring about accelerated metamorphosis in frog larvae (Swingle, 1922) and exogenous TSH administration induces hormone secretion by thyroid glands (Kerkof et al., 1963). In addition, thyroid glands of Necturuscan respond to implants of anterior pituitaries from Rana pipiens (Grant, 1930). Likewise, larvae of Rana clamitans implanted with a piece of an adult Necturus anterior pituitary showed metamorphic features (Charipper and Corey, 1930), suggest- ing that the Necturus pituitary gland is functional. In contrast, Necturus displays no evidence of metamorphosis when given T4, whole thyroid substance or thyroid implants (Swingle, 1922). In addition, when skin of a species capable of undergoing metamorphosis is transplanted to Necturus and the latter is given T4, the donor skin undergoes metamorphic changes, while that of the host is unaffected (Noble and Richards, 1931). This suggests that Necturus tissues are insensitive to T4, but the precise underlying mechanism remains unknown.

It has been suggested from an isotopic study that low receptor number may contribute to paedomorphosis in Necturus (Galton, 1985). Likewise, previous studies from our group, using RT-PCR failed to detect TRB mRNA in gill, muscle or liver tissues of Necturus (Safi et al., 1997). Since we obtained Necturus TR $\alpha$ and TRB specific probes (Safi et al., 2006), we therefore undertook in situ hybridization experiments to assess TR expression in several Necturus tissues. The expression of two TH-related genes was also studied. Cytosolic Thyroid Hormone-Binding Protein (CTHBP)-M2-pyruvate kinase encodes a cytosolic TH binding protein and stromelysin 3 is a direct TH target gene in Xenopus laevis. Stromelysin 3 is a particularly interesting case since this gene has been shown to be required for cell migration and apoptosis during tissue remodelling in Xenopus (Ishizuya-Oka et al., 2000, Fu et al., 2005). Close examination of all organs examined showed that $T R$ genes were expressed in many tissues like the brain, intestine or urinary bladder mucosa and muscle. In addition, we observed that expression patterns of CTHBP and ST3 are largely distinct from those of the TRs. The findings reported here as well as the fact that in vitro functional studies show Necturus TRs to be functional (Safi et al., 2006), suggest that peripheral organs should be sensitive to $\mathrm{TH}$. These 
findings thus contradict previously held concepts as to tissue insensitivity to $\mathrm{TH}$ in this species.

\section{Results}

\section{Histological assessment of Necturus maculosus tissues}

Precise dissection of three specimens of Necturus maculosus allowed the isolation of several tissues samples, which were used for in situ hybridization experiments. Tissue samples taken for study included the central nervous system (CNS) with certain sensory organs (eye and otic capsule), circulatory and respiratory systems (external gill, lung, heart), digestive system and accessory glands (stomach, intestine, liver, pancreas and spleen), urogenital system (kidney, urinary bladder, testis, ovary, oviduct, homologue of oviduct), as well as parts of the locomotor system (hindlimb, tail) including skeletic and muscular tissues.

Some sections were not hybridized and stained by routine trichrome staining (hematoxylin-eosin-safran) for histological assessment. Histological analysis revealed that some tissues obtained from reproductively competent adults showed characteristics of paedomorphic «larval» stages. For example, Necturus brains consist of a simple neural tube with primitive cerebral vesicles (namely diencephalon and telencephalic vesicles) and periventricular neuronal blastema (Fig. 1A-B). Skin, examined in hindlimb and tail sections, exhibited typical features of Urodela larval skin such as a four-layered structure (epidermidis, basement membrane, basement lamella and hypodermidis) and a relative paucity of melanophores. Intestine was seen to be as a weakly villous uni-stratified epithelium (Fig. 2A). Liver was characteristic of a granulopoietic larval organ (Delsol, 1995) (Fig. 3A). As usually described in Urodela larvae, endocrine islets were rare in the Necturus pancreas (Fig. 4A) (Delsol, 1995). Lung tissue showed a unistratified epithelium, devoid of septa and suggestive of a larval hydrostatic structure, consistent with the entirely aquatic life of Necturus (Delsol, 1995). Pronephrotic kidney of male specimens comprised the two characteristic parts of the Urodela order, i.e. the cranial «genital» part (connecting to testicular efferent ducts and including ducts for spermatozoids) and the caudal «urinary» part (including the proper pronephretic ducts) (Fig. 5A) (Delsol, 1995). Epiphyses of the hindlimb disclosed mild enchondral ossification, whereas diaphyses were formed by avascular lamellar periostic bone.

\section{CTHBP and stromelysin 3 gene expression in Necturus maculosus}

The genes encoding CTHBP (M2-pyruvate kinase) and stromelysin 3 are under the control of $\mathrm{TH}$ in many species and their expression has been succinctly described in some metamorphosing Amphibians such as Xenopus laevis and Rana catesbeiana (Shi et al., 1994). We studied their expression, as representative T3-regulated genes, in Necturus maculosus. Except for the gills and otic capsule, all Necturus tissues exhibited strong hybridization signals when CTHBP antisense probes were used. Diffuse expression was observed in skeletic muscles (hindlimb and tail) (Fig. 6D-E) and myocardium as well as liver (Fig. 3B), spleen and lung parenchyma. In the digestive system (stomach and intestine), expression was restricted to epithelial cells (Fig. 2B-C) as it was in the urinary bladder and the excretory ducts of testis, oviduct and homologue of oviduct. In the kidney, CTHBP gene was found to be weakly expressed in tubular structures suggestive of pronephretic ducts (Fig. 5B-C). Neuronal areas in telencephalon, diencephalon, mesencephalon (Fig. 1CD) and eye also expressed CTHBP.

Although less intense than CTHBP, stromelysin 3 gene expression roughly overlapped with that of CTHBP gene. Diffuse hybridization signals were seen in myocardium, lung and spleen and as an epithelium-restricted signal in digestive system, urinary bladder, testis, oviduct and homologue of oviduct. Stronger expression was evident in neuronal areas of telencephalon and diencephalons (Fig. 1E-F). No signal was observed in skeletic
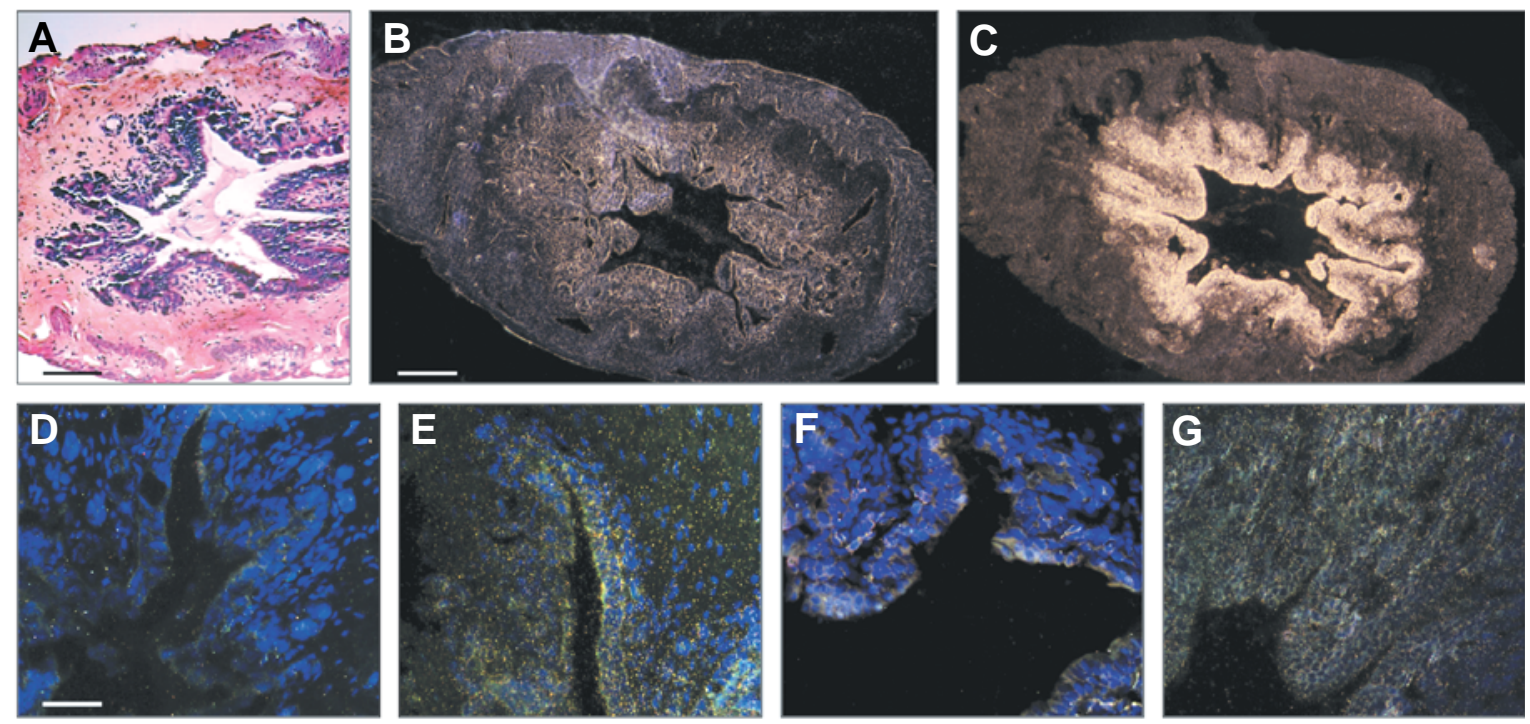

Fig. 2. Expression of $\boldsymbol{C T H B P}, \mathbf{T R} \boldsymbol{\alpha}$ and $\boldsymbol{T R \boldsymbol { \beta }}$ genes in Necturus maculosus intestine. Adjacent transversal sections of the intestine were stained with HES (A) (bar $=360 \mu \mathrm{m})$ or hybridized with either CTHBP sense (B) (bar for B,C represents $300 \mu \mathrm{m})$, CTHBP antisense (C), TR $\alpha$ sense (D), TR $\alpha$ antisense (E), TR $\beta$ sense (F), or TR $\beta$ antisense (G) probes (bar in D for D-G represents $250 \mu \mathrm{m}$ ). Expression was restricted to mucosa. 

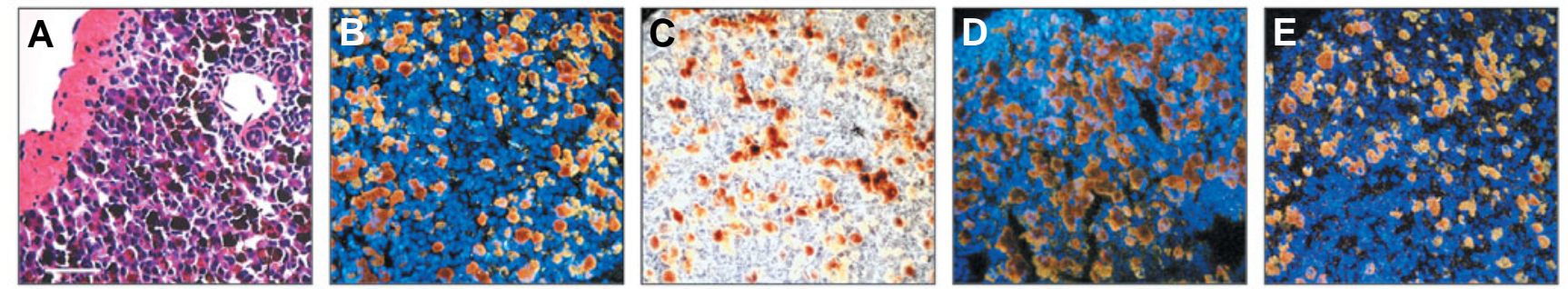

Fig. 3. Expression of CTHBP, TR $\boldsymbol{\alpha}$ and TR $\boldsymbol{\beta}$ genes in Necturus maculosus liver. Adjacent transversal sections of the liver were stained with HES (A) or hybridized with either CTHBP sense (B), CTHBP antisense (C), TR $\alpha$ antisense (D), or TR $\beta$ antisense (E) probes (bar represents $230 \mu \mathrm{m})$. CTHBP expression was diffuse in the whole gland, whereas hybridization signal using TR probes was similar to background labeling.

muscle, nor was it in the liver (Fig. 3C), eye and otic capsule. In the kidney, expression was specific to round structures suggestive of glomerules (Fig. 5D-E), whereas it was restricted to acini in the pancreas (Fig. 4D).

\section{Thyroid hormone receptor gene expression in Necturus maculosus}

Expression of $T R$ genes was studied on adjacent sections of Necturus tissues. This expression proved to be restricted to certain tissues such as the brain, muscle, digestive system, urinary bladder and pancreas. No signal was observed in either of the sensory organs examined (eye and otic capsule), nor in the kidney, genital system (testis, ovary, oviduct, homologue of oviduct), liver (Fig. 3D-E), or spleen.

In the brain, TR $\alpha$ gene expression was specifically found in the neuronal areas of telencephalon and diencephalon (Fig. 1G-H). In the muscle, expression was diffuse, both in skeletal muscle (hindlimb and tail) and myocardium (Fig. 6B-C). It was also diffuse in the uni-stratified epithelium of stomach, intestine (Fig. 2D-E) and urinary bladder. Only pancreas acini were labeled when $T R \alpha$ antisense probes were hybridized (Fig. 4E). The TR $\beta$ gene was also expressed in the periventricular neuronal areas of the brain (Fig. 11-J). Although less intense, an expression similar to that of $T R \alpha$ was also noticed in the pancreas (Fig. 4F). In intestine and stomach, TR $\beta$ gene expression was considered as too weak to be ascertained (Fig. 2F-G). It was not observed in the liver (Fig. 3F). In all tissues where both genes were expressed, hybridization signal was more marked for TR $\alpha$ probe than the $T R \beta$ one (see for example expression in the intestine, Fig. 2D-G).

\section{Discussion}

\section{TR expression}

Thyroid hormone receptors are thought to be the main mediators of TH action during Amphibian metamorphosis. A correlation between their expression and the morphological changes observed during metamorphosis is therefore expected. Several studies have reported dynamical TR mRNA expression in the metamorphosing Anuran Xenopus laevis (Baker and Tata, 1990, Yaoita and Brown, 1990, Banker et al., 1991, Kawahara et al., 1991). This expression pattern was latter confirmed by quantitative studies of TR proteins (Eliceiri and Brown, 1994). In whole tadpoles of this species, TR $\alpha$ genes have been found to be expressed as early as the immediate post-hatching stage (Baker and Tata, 1990, Yaoita and Brown, 1990, Kawahara et al., 1991). Their expression then increases throughout premetamorphosis, reaching a peak by early prometamorphosis (Baker and Tata,
1990, Yaoita and Brown, 1990, Kawahara et al., 1991, Eliceiri and Brown, 1994). In contrast, TR $\beta$ genes have low expression levels during premetamorphosis, but their mRNA and protein levels increase dramatically during metamorphosis (Yaoita and Brown, 1990, Kawahara et al., 1991, Eliceiri and Brown, 1994), in strong correlation with increases in plasma TH levels (Leloup and
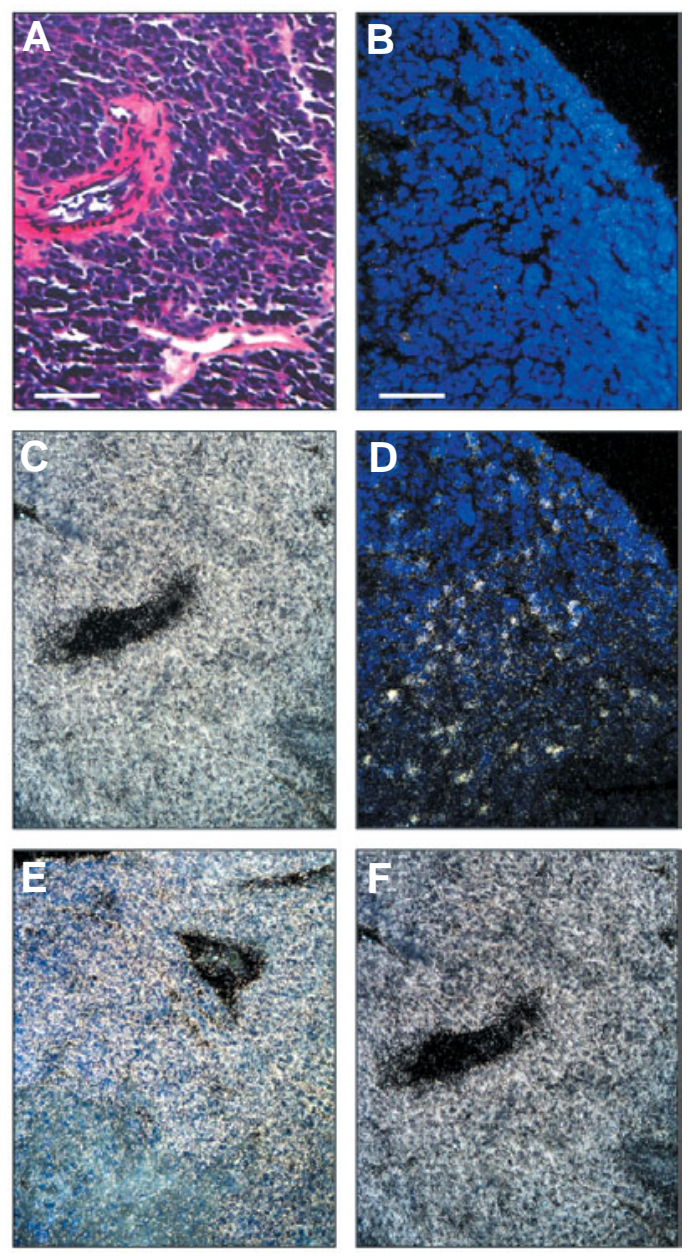

Fig. 4. Expression of $C T H B P$, stromelysin 3, TR $\alpha$ and $T R \beta$ genes in Necturus maculosus pancreas. Adjacent transversal sections of the pancreas were stained with HES (A) (bar represents $210 \mu \mathrm{m}$ ) or hybridized with either CTHBP sense (B), CTHBP antisense (C), stromelysin 3 antisense (D), TR $\alpha$ antisense (E), or TR $\beta$ antisense (F) probes (bar represents $180 \mu \mathrm{m})$. The four genes were diffusely expressed in the whole gland. 
Buscaglia 1977). TR $\beta$ genes are indeed among the early $\mathrm{TH}$ response genes isolated from subtractive differential screens for TH target-genes (Kanamori and Brown, 1996). This upregulation is believed to result from TH-mediated induction of the promoters of both $T R \beta$ genes. These inducible promoters contain at least a strong TRE by which TRs upregulate TR $\beta$ gene expression (Ranjan et al., 1994, Machuca et al., 1995, Wong et al., 1998). Although clearly less marked than that of TR $\beta$ mRNAs, upregulation of $\operatorname{TR} \alpha$ levels has also been reported at metamorphic climax (Yaoita and Brown, 1990). In the facultative paedomorphic Ambystoma mexicanum (Mexican axolotl), similar results showing dynamic expression patterns during premetamorphosis and $\mathrm{TH}$ induced metamorphosis were obtained using T3-binding studies (Galton, 1992) as well as by using specific RNA probes (Safi et al., 2004).

A strong correlation between TR expression levels and metamorphic change was also observed when $T R$ gene expression was analyzed in individual tissues (Yaoita and Brown, 1990, Wang and Brown, 1993, Shi et al., 1994, Wong and Shi, 1995). In general, TR gene expression has been found to be high in a given organ when metamorphosis takes place and low before and after metamorphosis. In the tail for example, TRgenes are expressed at low levels until climax when they are up-regulated, concurrent with rapid tail resorption. TR $\alpha$ and TR $\beta$ mRNA levels remains relatively low in Xenopusintestine throughout premetamorphosis but then TR $\beta$ s mRNA increases during the drastic remodeling of epithelial tissue (Shi et al., 1994, Wong and Shi, 1995). Likewise, TR mRNA levels are high in the hindlimb when limb morphogenesis takes place (Wang and Brown, 1993, Shi et al., 1994, Wong and Shi, 1995). Immunocytochemical analysis in liver, intestinal epithelium and hindlimb bud of Xenopus gave similar results when morphological changes were induced during natural and T3-induced metamorphosis (Fairclough and Tata, 1997). In all these studies, TR $\alpha$ mRNA and protein were generally more abundant than TR $\beta$ products.

Two studies have provided a more accurate picture of tissue distribution of TR mRNAs (Kawahara et al., 1991) and proteins (Fairclough and Tata, 1997) in Amphibians. The first showed TR distribution in Xenopus laevis at various larval stages and revealed expression of $\mathrm{TR} \alpha$ transcripts in the CNS, epithelial tissues of several organs (intestine, pharynx, liver, kidney and skin), muscular tissues (heart, tail, intestine and skeletal muscles) as well as with lower levels in connective tissues (Kawahara et al., 1991). During development, tissue distribution was not modified, but the spread and the intensity of the hybridization signal increased (Kawahara et al., 1991). No clear signal was observed when the Xenopus TR $\beta$ probe was hybridized to tissue samples (Kawahara et al., 1991). The second study provided evidence for TR $\alpha$ protein in liver, intestinal epithelium and hindlimb of Xenopus (Fairclough and Tata, 1997). To our knowledge, our present study is the first to properly address TRgene expression in an obligatory paedomorphic Amphibian. It shows that TR $\alpha$ gene is unequivocally expressed in Necturus maculosus. This expression pattern is strongly similar to that observed in Xenopus laevis, i.e. wide expression in tissues of various origins such as ectoderm-derived central nervous system, endoderm-derived epithelia of digestive and urinary organs, as well as mesoderm-derived muscular tissues (Kawahara et al., 1991). The expression of TRß gene is more questionable and, excepting the brain and the pancreas

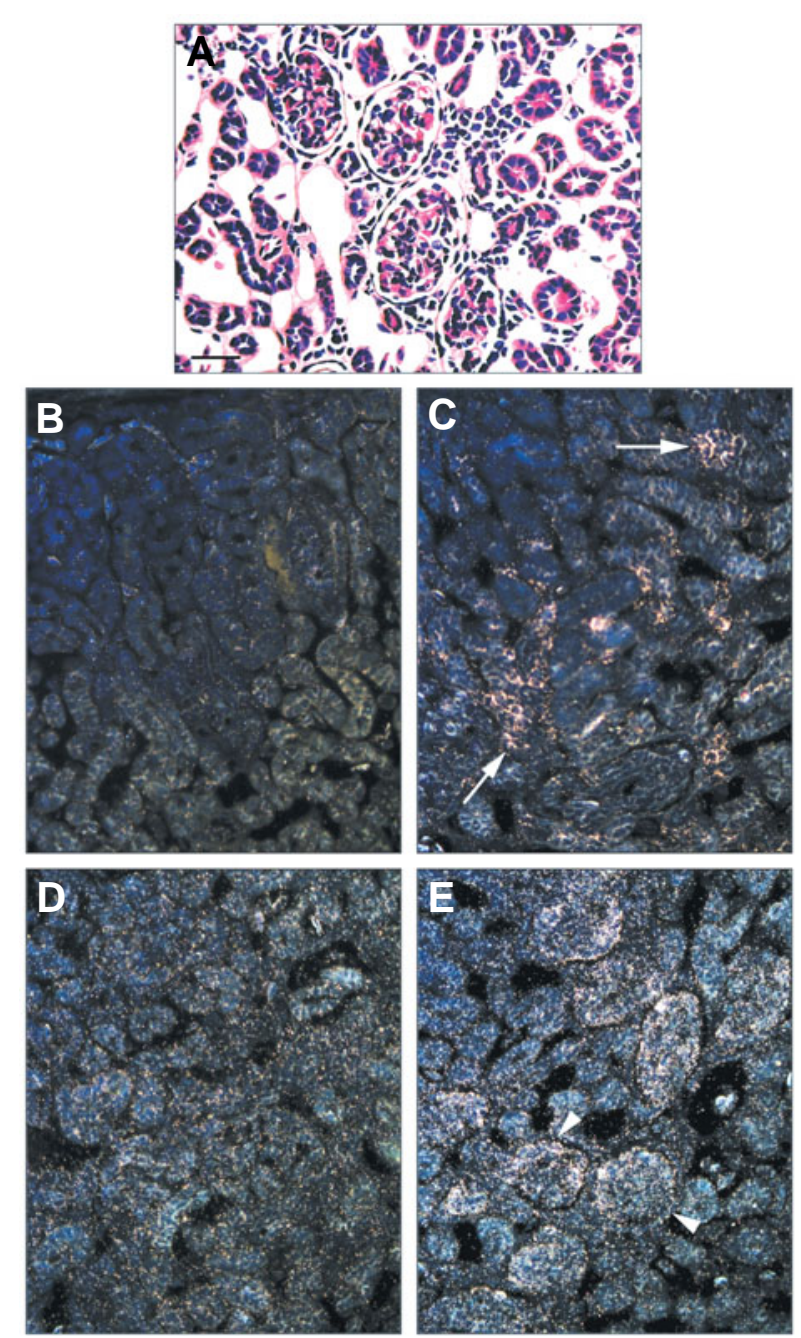

Fig. 5. Expression of CTHBP and stromelysin 3 genes in Necturus maculosus kidney. Adjacent transversal sections of the kidney were stained with HES (A) or hybridized with either CTHBP sense (B), CTHBP antisense (C), stromelysin 3 sense (D), or stromelysin 3 antisense (F) probes (bar represents $230 \mu \mathrm{m}$ ). CTHBP expression was restricted to tubular structures suggestive of pronephretic ducts (arrows), whereas stromelysin 3 expression was observed in glomerules (arrowheads).

where clear hybridization signals were observed, the signals obtained with the TR $\beta$ probe, for example in the intestinal epithelium, were too weak to draw firm conclusions about tissue distribution. This is reminiscent of the observations cited in Xenopus laevis using in situ hybridization (Kawahara et al., 1991). These findings may reflect an insufficient sensitivity of the technique and thus, TR $\beta$ gene expression cannot be excluded in the tissues where we did not find it. Indeed, we have recently observed TRR gene expression in Necturus tissues using RT-PCR (Safi et al., 2006). However, as observed in premetamorphotic Xenopus laevis (Baker and Tata, 1990, Yaoita and Brown, 1990, Banker et al., 1991, Kawahara et al., 1991), as well as in red blood cells of Rana catesbeiana tadpoles (Schneider et al., 1993), TRß gene expression is constantly lower than that of the TR $\alpha$ gene.

By unequivocally demonstrating the presence of TRs in Necturus maculosus, our study suggests that the markedly low 

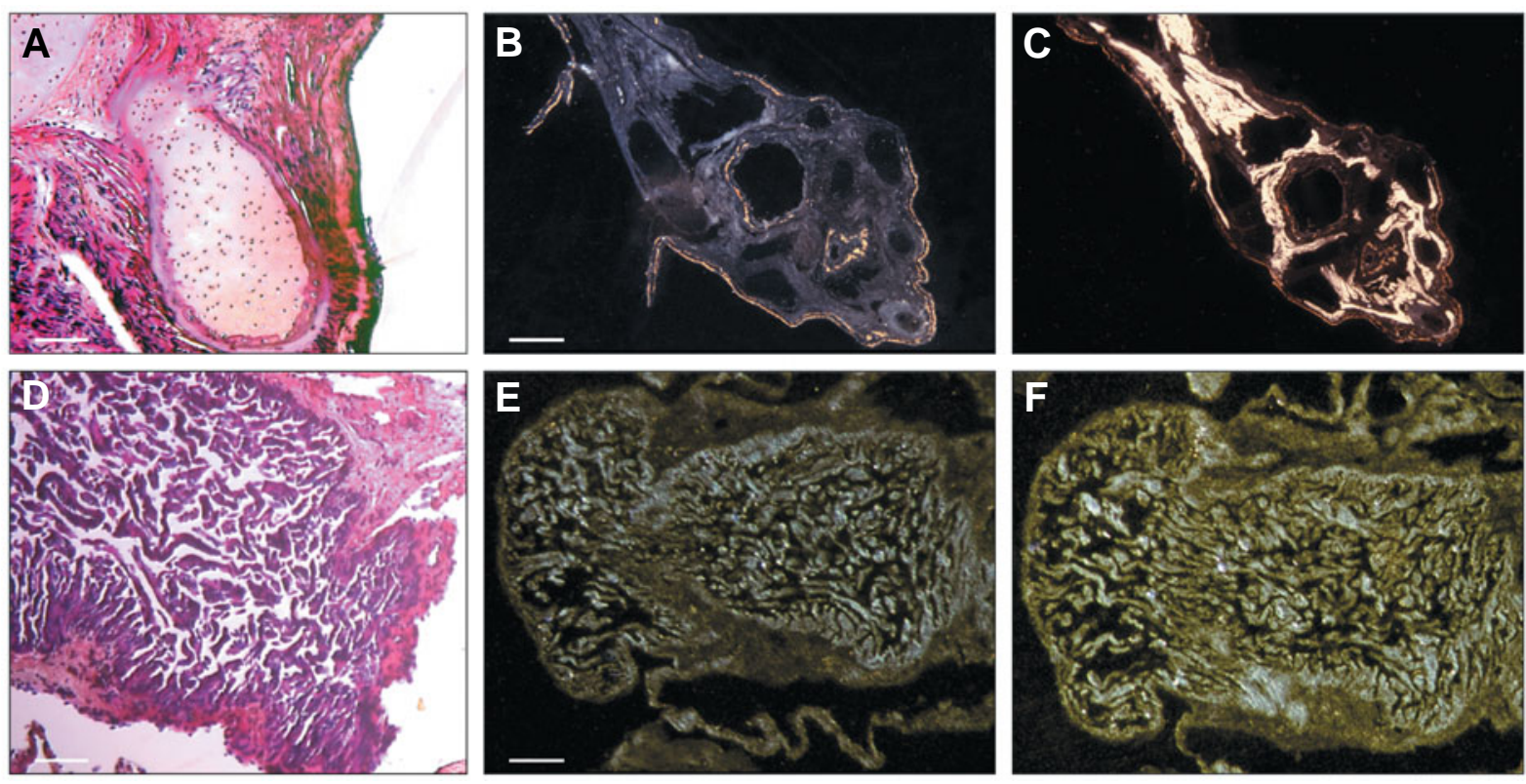

Fig. 6. Expression of CTHBP and TR $\boldsymbol{\alpha}$ genes in Necturus maculosus muscle and myocardium. Adjacent longitudinal sections of the caudal limb were stained with HES (A) ( bar represents $6.7 \mathrm{~mm}$ ) or hybridized with either CTHBP sense (B), or CTHBP antisense $\mathbf{( C )}$ probes (bar represents 800 $\mu \mathrm{m})$. CTHBP expression was intense in skeletal muscle. Adjacent longitudinal sections of the heart were stained with HES (D) (bar represents 390 $\mu \mathrm{m})$, hybridized with either TR $\alpha$ sense (E) or TR $\alpha$ antisense (F) probes (bar represents $470 \mu \mathrm{m})$. TR $\alpha$ expression was weak and restricted to the myocardium.

sensitivity of Necturustissues to TH is not due to a total lack of TR mRNAs as previously suggested (Yaoita and Brown, 1990).

\section{CTHBP and stromelysin 3}

The results obtained with $C T H B P$ and stromelysin 3 genes are consistent with those obtained in the Xenopus tadpole (Shi et al., 1994, Patterton et al., 1995, Ishizuya-Oka et al., 1996, Berry etal., 1998a, Berry et al., 1998b). Stromelysin 3 is weakly expressed in the intestine and totally absent from the tail of the premetamorphotic Xenopus (Patterton et al., 1995), a pattern we report here in Necturus. Likewise, as in Necturus, CTHBP mRNA levels are high in the Xenopus pre-metamorphic tail and intestine (Shi et al., 1994). In addition to the regulation of TR levels, a way for controlling metamorphosis is modulation of intracellular $\mathrm{TH}$ levels. CTHBP is a cytosolic protein that binds T3 and is likely to serve several roles including that of a buffer to modulate intracellular free T3 levels (reviewed in Shi, 2000)). In the present study, we showed that CTHBP is widely expressed in Necturus tissues, notably in all tissues where TR genes are expressed. Whether increased expression of CTHBP could account for metamorphic inhibition cannot be excluded from our non-quantitative study but the observation that its expression pattern is similar to that obtained in Xenopus argues against this hypothesis.

\section{Metamorphosis in Necturus?}

It is quite surprising to find measurable expression of TRgenes in an animal that has been described as TH-resistant. This is even more striking since our recent results also suggest that, at least $\mathrm{TR} \alpha$ protein is expressed in vivo for example in the intestine. In addition, functional studies carried out in our laboratory, suggest that both TR $\alpha$ and TR $\beta$ proteins behave in vitro as efficient T3inducible transcription factors (Safi et al., 2006). Indeed we found
Necturus TR $\alpha$ and TR $\beta$ genes to encode fully functional TRs that bind as heterodimers with RXR to DNA configured in various types of TREs. Necturus TRs also bind T3 and T4 with a high affinity ( $\mathrm{Kd}$ in the nano molar range) and transactivates target genes in response to TH with EC50 values very similar to the ones found for Xenopus TRs (Safi et al., 2006). The fact that TR genes are expressed and functional led us to question the insensitivity of Necturus tissues treated with extremely high amounts of exogenous $\mathrm{TH}$ (Swingle, 1922). In fact we recently demonstrated that, when observed at the gene expression level Necturus tissues are sensitive to $\mathrm{TH}$ treatment since we observed an upregulation of $\operatorname{TR} \alpha, \operatorname{TR} \beta$ and stromelysin 3 in gills. Our data which show $\operatorname{TR} \alpha$ levels comparable to those observed in adult mammals, but very low TR $\beta$ levels, lead to the suggestion that Necturus may have a relative resistance to $\mathrm{TH}$ due to the low amount of expressed receptor, but not a generalized resistance to the hormone. This suggests that detailed molecular analysis should detect a clear TH response in terms of gene activation patterns in tissues that express high levels of receptors, such as intestine, brain or pancreas.

Since we show that a $\mathrm{TH}$ response can occur in Necturus tissues and since the hypothalamo-pituitary-thyroid axis is functional, all our data are consistent with the following model: in the normal wild condition, a post-embryonic period of TH sensitivity would occur, leading to some modest changes, mainly at the biochemical or gene-regulation level (such as the partial larval to fast isomyosin transition). Other normal $\mathrm{TH}$ response pathways such as gill resorption would not occur because the relevant target genes have lost their ability to be regulated by $\mathrm{TH}$. This implies that paedomorphosis is not the absence of metamorphosis, but simply an attenuated and unnoticed response, that may even be diluted over a relatively long period of time. It is clear that this 
model should be tested using juvenile Necturus, in particular to study in vitro and in vivo the effect of $\mathrm{TH}$ in controlling gene expression. The situation in Necturus is quite different from that in other paedomorphic amphibians such as axolotl. In this species it is the "decision» to undergo metamorphosis itself that is affected whereas in Necturusis probably the process of metamorphosis itself that has been modified. In the axolotl, our previous work has clearly shown that TRs are indeed functional (Safi et al., 2004), whereas using a genetic approach these genes have been excluded as genes playing important roles in the evolution of paedomorphosis (Voss et al., 2000). The situation in Necturus is reminiscent to that which occurs in mammals, such as mice, were there is a post-embryonic period of high TH sensitivity (Fraichard et al., 1997).

\section{Materials and Methods}

\section{Preparation of Necturus maculosus tissues}

Samples of Necturus maculosus tissues were obtained from 3 wild North-American specimens provided by Dr. Planelles, from the French Museum d'Histoire Naturelle (Paris). They were 2 males and 1 female, which were killed by decapitation after anesthesia. After precise anatomic dissection (Gilbert, 1986), tissues were fixed by immediate immersion via phosphate buffer saline in freshly prepared $4 \%$ paraformaldehyde. They were fixed at $4^{\circ} \mathrm{C}$ for $16 \mathrm{~h}$, consecutively dehydrated in increasing concentration of ethanol, cleared in xylene, embedded in paraffin and stored at $-20^{\circ} \mathrm{C}$. Cartilage or bone containing tissues were immersed for $8 \mathrm{~h}$ before dehydratation in a formic acid-based solution to favor cryotome section. Six to $8 \mu \mathrm{m}$-thick sections were obtained from the paraffin blocks and then mounted on silane-treated glass slides (Sigma ${ }^{\circledR}$ ). Slides were incubated at $42^{\circ} \mathrm{C}$ for 2 days and stored at $4^{\circ} \mathrm{C}$ until use. For each tissue, sections not treated for hybridization were stained by routine trichrome staining (hematoxylin-eosin-safran) for histological assessment.

\section{Preparation of radiolabeled RNA probes}

Antisense and sense ${ }^{35} \mathrm{~S}$-labeled RNA probes were prepared from Necturus maculosus c-erbA $\alpha$ and c-erbA $\beta$ cDNA (Safi et al., 1997), as well as from CTHBP (M2 pyruvate kinase) and stromelysin 3 cDNAs, which were both cloned by RT-PCR using primers chosen in inter-species conserved regions. These primers are available from the authors upon request. All cDNAs were cloned in the pBluescript II KS plasmid (Stratagene $\AA^{\circledR}$ ). Transcription with T7 polymerase (Stratagene ${ }^{\circledR}$ ) from Hindlllinearized plasmids generated radiolabeled antisense probe for c-erbA $\alpha$ and c-erbA $\beta$ in presence of $\alpha-{ }^{35}$ S-CTP. Transcription with T3 polymerase (Stratagene $\AA$ ) from BamHI-linearized plasmids generated sense probe for c-erbA $\alpha$ and c-erbA $\beta$. The c-erbA $\alpha$ and c-erbA $\beta$ probes used in this study encompassed the region coding the $C, D$ and $E$ domains of the proteins. Transcription with T3 polymerase from Notl-linearized plasmids generated antisense probe for CTHBP and ST3, whereas sense probe were obtained from Xhol-linearized plasmids by using T7 polymerase. All plasmids were degraded by RNAse-free DNAse (Promega ${ }^{\circledR}$ ) and the phenol-chloroform-extracted probes were precipitated and purified using Quick Spin Columns (G-50 Sephadex fine ${ }^{\circledR}$ ). The average probe size was 300 bp after partial alkaline hydrolysis (Cox et al., 1984, Angerer et al., 1987, Angerer et al., 1989).

\section{In situ hybridization experiments}

In situ hybridization experiments were performed on serial consecutive sections from the same paraffin blocks. Sections were dewaxed, rehydrated and pretreated with $1 \mu \mathrm{g} \cdot \mathrm{ml}^{-1}$ of proteinase $\mathrm{K}$. Then slides were treated with $0.1 \mathrm{M}$ triethanolamine (in PBS, $\mathrm{pH}$ 8.0) and acetic anhydre $0.25 \%$ for $10 \mathrm{~min}$ at room temperature, in order to block non-specific binding of probes to amino residues. After dehydratation in $30 \%, 70 \%$,
$95 \%$ and $100 \%$ ethanol, the sections were hybridized according to the recommendations of Cox (Cox et al., 1984), with $10^{6} \mathrm{dpm}$ of ${ }^{35} \mathrm{~S}$-labeled probe at $60^{\circ} \mathrm{C}$ for $16 \mathrm{~h}$ in hybridization buffer (containing $50 \%$ deionized formamide, $20 \mathrm{mM}$ tris- $\mathrm{HCl}$, pH 8.0, $5 \mathrm{mM}$ EDTA, $300 \mathrm{mM} \mathrm{NaCl}, 10 \%$ dextran sulfate, Denhardts' solution $1 \mathrm{X}, 100 \mathrm{mM}$ dithiothreitol). This was followed by a high stringency wash for $30 \mathrm{~min}$, at $65^{\circ} \mathrm{C}$ in solution containing $100 \mathrm{mM}$ dithiothreitol. After treatment with RNAse A $\left(20 \mu \mathrm{g} . \mathrm{ml}^{-}\right.$ 1) for $1 \mathrm{~h}$ at $37^{\circ} \mathrm{C}$, sections were washed for $15 \mathrm{~min}$ in $2 \mathrm{X}$ standard saline citrate (SSC) and for $15 \mathrm{~min}$ in $0.1 \mathrm{XSSC}$ at $65^{\circ} \mathrm{C}$, dehydrated in alcohol and dried.

After hybridization, slides were immersed for autoradiographic detection of the hybrids in Kodak ® NTB2 emulsion (diluted 1:1 with $0.6 \mathrm{M}$ ammonium acetate) and stored at $4^{\circ} \mathrm{C}$. The slides were then exposed for 3 to 4 weeks (c-erbA $\alpha, c-e r b A \beta$ and ST3 probes) or 5 to 7 days (CTHBP probe), developed and stained with bisbenzimide (Hoechst $33258 \AA$ intercaling DNA dye) to visualize the nuclei and mounted in glycergel $\left(\right.$ Sebia $\left.{ }^{\circledR}\right)$. Sections were examined under dark field and epifluorescence illumination with Leica ${ }^{\circledR}$ MZ FLIII and Axioskop 50Zeiss ${ }^{\circledR}$ microscopes, respectively. Control hybridization of similar sections with sense probe did not produce any specific detectable signal above background.

\section{Acknowledgements}

We would like to thank Dr Kawahara for his advice about in situ hybridization experiments and Hector Escriva and Michael Schubert for critical reading of the manuscript. We are indebted to Barbara Demeneix for correction of the English style of the paper and are also extremely grateful to Gabrielle Planelles for providing us with Necturus specimens. R.S. holds a fellowship from the Ligue Nationale contre le Cancer. V.V.$G$. was a recipient of a grant from Schering $S A$ and Lille University of Medicine. We thank MENRT, CNRS, ARC, Ligue Régionale Contre le Cancer du Rhône et de la Loire for financial support.

\section{References}

ANGERER, L.M., COX, K.H. and ANGERER, R.C. (1987). Demonstration of tissuespecific gene expression by in situ hybridization. Methods Enzymo/152: 64961.

ANGERER, L.M., DOLECKI, G.J., GAGNON, M.L., LUM, R., WANG, G., YANG, Q., HUMPHREYS, T. and ANGERER, R.C. (1989). Progressively restricted expression of a homeo box gene within the aboral ectoderm of developing sea urchin embryos. Genes Dev 3: 370-83.

BAKER, B.S. and TATA, J.R. (1990). Accumulation of proto-oncogene c-erb-A related transcripts during Xenopus development: association with early acquisition of response to thyroid hormone and estrogen. EMBO J9: 879-85.

BANKER, D.E., BIGLER, J. and EISENMAN, R.N. (1991). The thyroid hormone receptor gene (c-erbA alpha) is expressed in advance of thyroid gland maturation during the early embryonic development of Xenopus laevis. Mo/ Cel/ Bio/11: 5079-89.

BERRY, D.L., ROSE, C.S., REMO, B.F. and BROWN, D.D. (1998a). The expression pattern of thyroid hormone response genes in remodeling tadpole tissues defines distinct growth and resorption gene expression programs. Dev Bio/203: 24-35.

BERRY, D.L., SCHWARTZMAN, R.A. and BROWN, D.D. (1998b). The expression pattern of thyroid hormone response genes in the tadpole tail identifies multiple resorption programs. Dev Bio/203: 12-23.

CHARIPPER, H.A. and COREY, E.L. (1930). Studies on amphibian endocrines. V. Accelerated metamorphosis of Rana clamitans larvae by means of implants of fresh anterior pituitary from adult Necturus maculosus. Anat Record 45: 258.

COX, K.H., DELEON, D.V., ANGERER, L.M. and ANGERER, R.C. (1984). Detection of mRNAs in sea urchin embryos by in situ hybridization using asymmetric RNA probes. Dev Bio/101: 485-502.

DELSOL, M. (1995). Tome XIV, fascicule IA. Amphibiens. Anatomie et Physiologie comparées de l'adulte et de la larve. La métamorphose et son déterminisme. Appareil urogénital. In Traité de Zoologie. Anatomie, Systématique, Biologie, (ed. GRASSÉ, P. P.). Masson, Paris, pp.1-1355. 
ELICEIRI, B.P. and BROWN, D.D. (1994). Quantitation of endogenous thyroid hormone receptors alpha and beta during embryogenesis and metamorphosis in Xenopus laevis. J Biol Chem 269: 24459-65.

FAIRCLOUGH, L. and TATA, J.R. (1997). An immunocytochemical analysis of the expression of thyroid hormone receptor alpha and beta proteins during natural and thyroid hormone- induced metamorphosis in Xenopus. Dev Growth Differ 39: 273-83.

FRAICHARD, A., CHASSANDE, O., PLATEROTI, M., ROUX, J.P., TROUILLAS, J., DEHAY, C., LEGRAND, C., GAUTHIER, K., KEDINGER, M., MALAVAL, L. et al. (1997). The T3R alpha gene encoding a thyroid hormone receptor is essential for post-natal development and thyroid hormone production. EMBOJ 16: $4412-20$.

FU, L., ISHIZUYA-OKA, A., BUCHHOLZ, D.R., AMANO, T., MATSUDA, H. and SHI, Y.B. (2005). A causative role of stromelysin-3 in extracellular matrix remodeling and epithelial apoptosis during intestinal metamorphosis in Xenopus laevis. J Biol Chem 280: 27856-65.

GALTON, V.A. (1985). 3,5,3'-Triiodothyronine receptors and thyroxine 5'monodeiodinating activity in thyroid hormone-insensitive amphibia. Gen Comp Endocrino/57: 465-71.

GALTON, V.A. (1992). Thyroid hormone receptors and iodothyronine deiodinases in the developing Mexican axolotl, Ambystoma mexicanum. Gen Comp Endocrino/85: 62-70.

GILBERT, S.G. (1986). Pictorial anatomy of the Necturus. University Washington Press, Seattle, pp.1-47.

GRANT, M.P. (1930). The release of follicular colloid from the thyroid of Necturus maculosus following heteroplastic anterior-pituitary implants. Anat Record 46: 205-21.

HARRIS, J.P. (1956). Field Lab Invest 24: 21, cité in Larsen 1968.

ISHIZUYA-OKA, A., LI, Q., AMANO, T., DAMJANOVSKI, S., UEDA, S. and SHI, Y.B. (2000). Requirement for matrix metalloproteinase stromelysin-3 in cell migration and apoptosis during tissue remodeling in Xenopus laevis. J Cell Biol 150: $1177-88$.

ISHIZUYA-OKA, A., UEDA, S. and SHI, Y.B. (1996). Transient expression of stromelysin-3 mRNA in the amphibian small intestine during metamorphosis. Cell Tissue Res 283: 325-9.

KANAMORI, A. and BROWN, D.D. (1996). The analysis of complex developmental programmes: amphibian metamorphosis. Genes Cells 1: 429-35.

KAWAHARA, A., BAKER, B.S. and TATA, J.R. (1991). Developmental and regional expression of thyroid hormone receptor genes during Xenopusmetamorphosis. Development 112: 933-43.

KERKOF, P.R., TONG, W. and CHAIKOFF, I.L. (1963). I131 utilization by Salamanders:- Taricha, Amphiuma and Necturus. Endocrinology 73: 185-92.

LARSEN, J.H., JR. (1968). Ultrastructure of thyroid follicle cells of three salamanders (Ambystoma, Amphiuma and Necturus) exhibiting varying degrees of neoteny. J Ultrastruct Res 24: 190-209.

LELOUP, J. and BUSCAGLIA, M. (1977). La triiodothyronine: hormone de la métamorphose des Amphibiens. C R Acad Sci284: 2261-3.

MACHUCA, I., ESSLEMONT, G., FAIRCLOUGH, L. and TATA, J.R. (1995). Analysis of structure and expression of the Xenopus thyroid hormone receptorbeta gene to explain its autoinduction. Mol Endocrino/9: 96-107.

NOBLE, G.K. and RICHARDS, L.B. (1931). The criteria of metamorphosis in urodeles. Anat Record 48: 58.

PATTERTON, D., HAYES, W.P. and SHI, Y.B. (1995). Transcriptional activation of the matrix metalloproteinase gene stromelysin-3 coincides with thyroid hormone-induced cell death during frog metamorphosis. Dev Bio/167: 252-62.
RANJAN, M., WONG, J. and SHI, Y.B. (1994). Transcriptional repression of Xenopus TR beta gene is mediated by a thyroid hormone response element located near the start site. J Biol Chem 269: 24699-705.

ROSENKILDE, P. and USSING, A.P. (1996). What mechanisms control neoteny and regulate induced metamorphosis in urodeles? Int J Dev Bio/40: 665-73.

SAFI, R., BEGUE, A., HANNI, C., STEHELIN, D., TATA, J.R. and LAUDET, V. (1997). Thyroid hormone receptor genes of neotenic amphibians. JMO/EVo/44: 595-604.

SAFI, R., BERTRAND, S., MARCHAND, O., DUFFRAISSE, M., DE LUZE, A., VANACKER, J.M., MARANINCHI, M., MARGOTAT, A., DEMENEIX, B. and LAUDET, V. (2004). The axolotl (Ambystoma mexicanum), a neotenic amphibian, expresses functional thyroid hormone receptors. Endocrinology 145: 76072.

SAFI, R., VLAEMINCK-GUILLEM, V., DUFFRAISSE, M., SEUGNET, I., PLATEROTI, M., MARGOTAT, A., DUTERQUE-COQUILLAUD, M., CRESPI, E.J., DENVER, R.J., DEMENEIX, B. et al. (2006). Paedomorphosis revisited: Thyroid hormone receptors are functional in Necturus maculosus. Evol Dev: in press.

SCHNEIDER, M.J., DAVEY, J.C. and GALTON, V.A. (1993). Rana catesbeiana tadpole red blood cells express an alpha, but not a beta, c-erbA gene. Endocrinology 133: 2488-95.

SHI, Y.B. (2000). Amphibian Metamorphosis. From Morphology to Molecular Biology. John Wiley \& Sons, New York, pp.1-288.

SHI, Y.B., LIANG, V.C., PARKISON, C. and CHENG, S.Y. (1994). Tissue-dependent developmental expression of a cytosolic thyroid hormone protein gene in Xenopus: its role in the regulation of amphibian metamorphosis. FEBS Lett355: 61-4.

STEBBINS, R.C. and COHEN, N.W. (1997). A Natural History of Amphibians. Princeton University Press, Princeton, New Jersey, USA.

SWINGLE, W.W. (1922). Experiments on the metamorphosis of neotenous amphibians. J EXp Zoo/36: cité in Grant 1930.

TATA, J.R., BAKER, B.S., MACHUCA, I., RABELO, E.M. and YAMAUCHI, K. (1993). Autoinduction of nuclear receptor genes and its significance. J Steroid Biochem Mol Biol 46: 105-19.

VOSS, S.R., SHAFFER, H.B., TAYLOR, J., SAFI, R. and LAUDET, V. (2000). Candidate gene analysis of thyroid hormone receptors in metamorphosing vs. nonmetamorphosing salamanders. Heredity 85 (Pt 2): 107-14.

VOSS, S.R. and SMITH, J.J. (2005). Evolution of salamander life cycles: a majoreffect quantitative locus contributes to discrete and continuous variation for metamorphic timing. Genetics 170: 275-81.

WANG, Z. and BROWN, D.D. (1993). Thyroid hormone-induced gene expression program for amphibian tail resorption. J Biol Chem 268: 16270-8.

WONG, J., LIANG, V.C., SACHS, L.M. and SHI, Y.B. (1998). Transcription from the thyroid hormone-dependent promoter of the Xenopus laevis thyroid hormone receptor betaA gene requires a novel upstream element and the initiator, but not a TATA Box. J Biol Chem 273: 14186-93.

WONG, J. and SHI, Y.B. (1995). Coordinated regulation of and transcriptional activation by Xenopus thyroid hormone and retinoid $\mathrm{X}$ receptors. $J$ Biol Chem 270: 18479-83.

YAOITA, Y. and BROWN, D.D. (1990). A correlation of thyroid hormone receptor gene expression with amphibian metamorphosis. Genes Dev 4: 1917-24.

Received: September 2005

Reviewed by Referees: October 2005

Modified by Authors and Accepted for Publication: February 2006 Published Online: April 2006 